\title{
PARTIAL ROOTZONE DRYING ADVANCES FRUIT MATURITY OF ROYAL GALA APPLE
}

\section{EL RIEGO PARCIAL DE LA RAÍZ ADELANTA LA MADURACIÓN DE LA MANZANA ROYAL GALA}

\author{
Jorge A. Zegbe ${ }^{1,2 \star}$, M. Hossein Behboudian ${ }^{1}$ and Alexander Lang ${ }^{3}$
}

\begin{abstract}
${ }^{1}$ Institute of Agriculture and Environment, Massey University. Private Bag 11 222, Palmerston North, New Zealand. ${ }^{2}$ Campo Experimental Zacatecas, Instituto Nacional de Investigaciones Forestales, Agrícolas y Pecuarias. Apartado Postal No. 18. 98500, Calera de V. R., Zacatecas, México. Tel.: (52) 55-38-71-87-00 Ext: 82314. ${ }^{3}$ Sandy Lang Ltd., 402 Muritai Road Eastbourne 5013, Wellington, New Zealand.
\end{abstract}

* Autor para correspondencia: zegbe.jorge@inifap.gob.mx

\section{SUMMARY}

Partial rootzone drying (PRD) is a feasible irrigation strategy for saving water, which might save up to $50 \%$ water, while maintaining apple (Malus domestica Borkh) yield. More information is available on the effect of PRD on yield and fruit quality than on fruit maturity advancement (FMA). Therefore, the effect of PRD on FMA of Royal Gala apples grown in a dry area of New Zealand was studied. The irrigation treatments were commercial irrigation $(\mathrm{Cl})$ and PRD. Fruit growth and FMA were measured. FMA was estimated based on mean fresh mass of fruit (MFMF), fruit skin color (FSC), fruit diameter $(F D)$, fruit volume (FV), fruit density (FDen), flesh firmness (FF), total soluble solids concentration (TSSC), dry mass concentration of fruit (DMCF), and starch pattern index (SPI). MFMF, FSC, FD, FV, FDen, and DMCF were similar between $\mathrm{Cl}$ and PRD fruit. However, compared to $\mathrm{Cl}$ fruit, PRD fruit showed a tendency for enhancing FF and TSSC. SPI was higher in PRD fruit than in $\mathrm{Cl}$ fruit. Canonical discriminant analysis showed that fruit quality attributes collectively accounted for the significant separation between $\mathrm{Cl}$ and PRD fruit. The separation was weighed toward higher SPI, which was indicative of FMA in PRD treatment. This has important implications for early marketing. So, PRD application may improve FMA and save irrigation water by $52 \%$. The PRD could therefore be recommended for similar agro-ecological areas of the world.

Index words: Malus domestica, reduced irrigation, water relationships, fruit quality.

\section{RESUMEN}

El riego parcial de la raíz (PRD) es una estrategia factible para el ahorro de agua, el cual puede ser de hasta $50 \%$ del agua mientras que el rendimiento del manzano es mantenido. Para manzano (Malus domestica Borkh) y otros cultivos hay más información disponible sobre el efecto del PRD en el rendimiento y calidad de la fruta que en el adelanto en la madurez de la fruta (FMA). Por lo tanto, se estudió el efecto del PRD en la FMA de la manzana Royal Gala cultivada en una área seca de Nueva Zelandia. Los tratamientos de riego fueron: riego comercial $(\mathrm{Cl})$ y PRD. Se midió el crecimiento del fruto y FMA. Está última variable se evaluó en términos de la masa promedio del fruto (MFMF), color de la epidermis (FSC), diámetro (FD), volumen (FV), densidad (FDen), firmeza (FF), concentración de sólidos solubles totales (TSSC), concentración de la materia seca (DMCF) e índice de almidón (SPI). MFMF, FSC, FD, FV, FDen y DMCF fueron similares entre la fruta con $\mathrm{Cl}$ y PRD. Sin embargo, al comparar la fruta con $\mathrm{Cl}$, la de PRD mostró una tendencia a mejorar la FF y la TSSC. El SPI fue mayor en la fruta con PRD que en la fruta con $\mathrm{Cl}$. El análisis discriminante canónico mostró que los atributos de calidad del fruto, considerados colectivamente, explicaron significativamente la separación entre la fruta con $\mathrm{Cl}$ y PRD. La diferencia estuvo inclinada hacia un alto SPI, el cual es indicativo de un FMA en el tratamiento con PRD. Esto tiene importantes implicaciones para la comercialización temprana. Así, la aplicación del PRD puede mejorar el FMA y ahorrar $52 \%$ del agua de riego. El PRD podría, por lo tanto, ser recomendando para áreas agro-ecológicas similares del mundo.

Palabras calve: Malus domestica, riego reducido, relaciones hídricas, calidad de la fruta.

\section{INTRODUCTION}

Water management in agriculture is crucial to poverty reduction, food security, and environmental protection. Over the last 30 years the global boom in groundwater use for irrigation in regions subjected to extended dry seasons has led to water shortages for agriculture. This is particularly true for arid and semiarid regions where apples (Malus domestica Borkh) trees are grown and their irrigation is essential for meeting high yields and adequate fruit quality standards (Behboudian et al., 2011). Partial root zone drying (PRD) is an irrigation strategy developed for saving water (Loveys et al., 2000). PRD has been successfully applied to apples without compromising yield while saving water (e.g. Einhorn and Caspari, 2004). However, PRD's effect on apple fruit quality has not been consistent (Behboudian et al., 2011). For example, Caspari et al. (2004) showed that for Fuji apple fruit quality was the same between fully irrigated and PRD treatments. But for the same cultivar Leib et al. (2005) observed higher total soluble solids concentration (TSSC) in PRD fruit than in fully-irrigated fruit. Fallahi et al. (2008) reported advanced fruit maturity, in terms of lower flesh firmness and higher starch degradation index, in PRD fruit compared to fully-irrigated fruit. Both advanced maturity and higher TSSC have important implications for fruit marketing and consumer preference.

This experiment was set up in a commercial orchard in Hawke's Bay, which is the main apple producing region of New Zealand. The objective was to study the effect of PRD on FMA of Royal Gala apples grown in a commercial orchard, to test the hypothesis that PRD would induce FMA in Royal Gala apples grown in a dry area of New Zealand. 


\section{MATERIALS AND METHODS}

The experiment was conducted in a commercial orchard in Havelock North (latitude $39^{\circ} 39^{\prime}$ S, longitude 176 53' E, elevation $5 \mathrm{~m}$ ), New Zealand, during the 2001-02 growing season. The area has a temperate climate with average annual values of $565 \mathrm{~mm}$ for rainfall and $781 \mathrm{~mm}$ for potential evapotranspiration. The orchard soil was sandy silt loam. The experimental block consisted of four rows of 25-year-old Royal Gala on MM-106 rootstocks. The trees were spaced at $5 \mathrm{~m}$ between rows and $4 \mathrm{~m}$ within rows and trained as a central leader. Trees received standard cultural practices used for local commercial production including fertilisation, fruit thinning, drip irrigation, and pest control as needed.

A total of 32 experimental trees were divided into four blocks. Each block had two plots of four trees each. At least two guard trees at each end surrounded the experimental plots. There was a guard tree row between experimental blocks. Two treatments were randomly allocated within each block. Treatments were: 1) commercial irrigation (CI) as control and partial rootzone drying (PRD). In controls, irrigation was applied by the grower following commercial practice based on meteorological data collected from a local weather station. The PRD irrigation was applied by alternating the irrigation from the wetted side to the dry side when the volumetric soil water content $(\theta)$ decreased to between 0.12 and $0.18 \mathrm{~m}^{3} \mathrm{~m}^{-3}$. The $\mathrm{Cl}$ and PRD trees were drip irrigated to field capacity $\left(0.27 \mathrm{~m}^{3} \mathrm{~m}^{-3}\right)$ using one irrigation pipe placed on each side of the tree row. Four emitters per tree, two on each pipe line, were placed $50 \mathrm{~cm}$ away from the tree trunk. The discharge from each emitter was $4 \mathrm{~L} \mathrm{~h}^{-1}$. During the entire growing season and after seven irrigation episodes, $\mathrm{PRD}$ and $\mathrm{Cl}$ trees received a total of $175 \mathrm{~mm}$ and $363 \mathrm{~mm}$ of applied water, respectively. The soil was covered with clear polyethylene to keep the rain out. This was done starting from 36 days after full bloom (DAFB), which occurred on 30 September 2001.

The $\theta$ was measured twice a month by time domain reflectometry (TDR, model 1502C $\AA$, Tektronix Inc.; Beaverton, OR, USA). One pair of TDR probes on each side of the PRD trees and one pair on $\mathrm{Cl}$ trees per experimental plot were set up permanently as detailed by Zegbe and Behboudian (2008) (Figure 1). On 93 DAFB, at fruit expansion, midday leaf water potential $\left(\Psi_{\text {leaf }}\right)$ was measured once on four leaves per plot between 12:00 and 13:30 hours with a pressure bomb (Soil Moisture Equipment Corp.; Santa Barbara, CA, USA). The photosynthetic photon flux for this occasion was $669 \pm 26 \mathrm{mmol} \mathrm{m} \mathrm{m}^{-2} \mathrm{~s}^{-1} \pm$ standard deviation.

Fruit equatorial diameter from ten fruits randomly selected at the outer and middle part of each tree canopy was measured twice a month with a digital hand-held calliper (Digimatic, model 50-321®; Mitutoyo Co., Japan). Readings were taken from 55 DAFB to 135 DAFB. At harvest (149 DAFB), from the two central trees, 10 fruit per plot were hand-picked randomly for fruit quality assessment. Fruit were individually weighed with an analytical balance (Mettler Instrument AG CH-8606®; Greifensee-Zurich, Switzerland). Equatorial diameter from each fruit was measured with the same device described previously. Fruit density $\left(\mathrm{g} \mathrm{cm}^{-3}\right)$ was determined as fruit mass per unit of volume. Fruit volume was obtained by water displacement. Fruit skin colour was measured on two opposite sides in the equatorial part of each fruit with a portable tristimulus colorimeter (Minolta CR-200®; Osaka, Japan) previously calibrated with a green plate (CR-A47 G).

After removing the fruit skin, two flesh firmness determinations were done on the same spots used for skin colour measurements. A press-mounted Effegi penetrometer (model FT 327®; Alfonsine, Italy) was used for measuring flesh firmness. A hand-held refractometer with automatic temperature compensation (ATC-1 Atago ${ }^{\circledR}$; Tokyo, Japan) was used for determining the total soluble solids concentration. Starch pattern index was determined according to Reid et al. (1982); therefore the hydrolysis of starch was ranked on a scale of 0 (100\% starch) to 6 (no starch). Dry mass concentration was measured by taking $25 \mathrm{~g}$ of fresh cortical tissue samples from each fruit. Samples were oven-dried at $65^{\circ} \mathrm{C}$ for one week to constant mass.

The data were analysed by complete randomised block model using the GLM procedure of SAS software (SAS Institute, Cary, NC, USA). The variables expressed in discrete unit were square-root transformed. Means were reported after back transforming. Treatment means were separated by least significant difference (LSD) test at $P \leq 0.05$. Fruit weight was used as covariate to assess fruit quality attributes. Data were also examined using canonical discriminant analysis (CDA) to have an overview of the fruit quality attributes collectively and to identify the major sources for the differences between irrigation treatments. For this, the CANDISC procedure of SAS was used.

\section{RESULTS AND DISCUSSION}

The difference in $\theta$ between $\mathrm{Cl}$ and non-irrigated side of PRD was significant on 50, 64, and 121 DAFB (Figure 2). Values of $\theta$ in irrigated side of PRD were similar than those of $\mathrm{Cl}$. The leaf xylem water potential $\left(\psi_{\text {leaf }}\right)$ was measured at midday in one occasion on 93 DAFB. The $\psi_{\text {leaf }}$ was statistically similar $(\mathrm{LSD}=-0.2)$ between $\mathrm{Cl}\left(\Psi_{\text {leaf }}=-1.0\right)$ and $\mathrm{PRD}$ $\left(\Psi_{\text {leaf }}=-1.1\right)$. Research in this laboratory has shown that reduced irrigation (deficit irrigation and PRD) will affect apple fruit quality if a medium to severe water stress develops. 


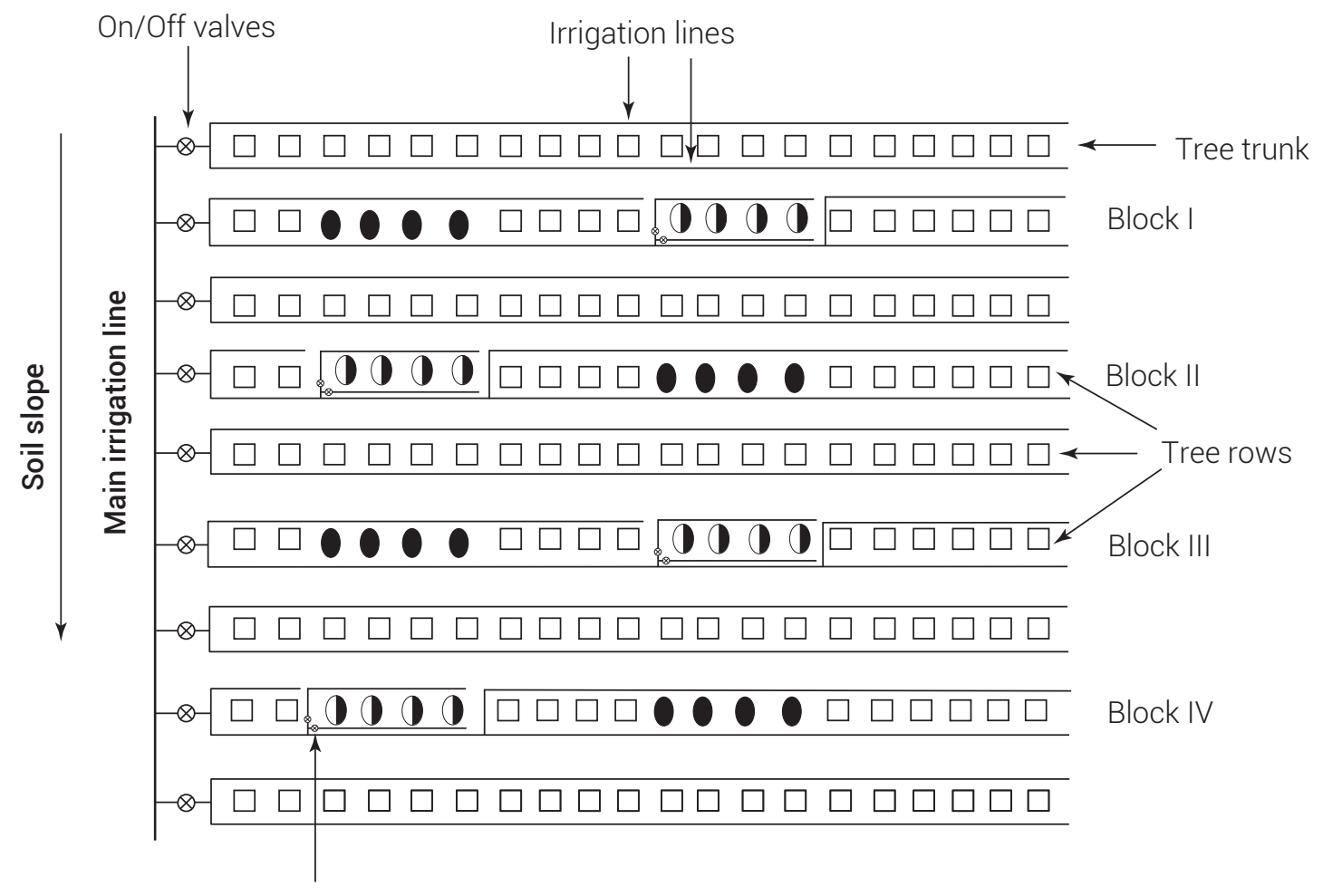

On/Off valves
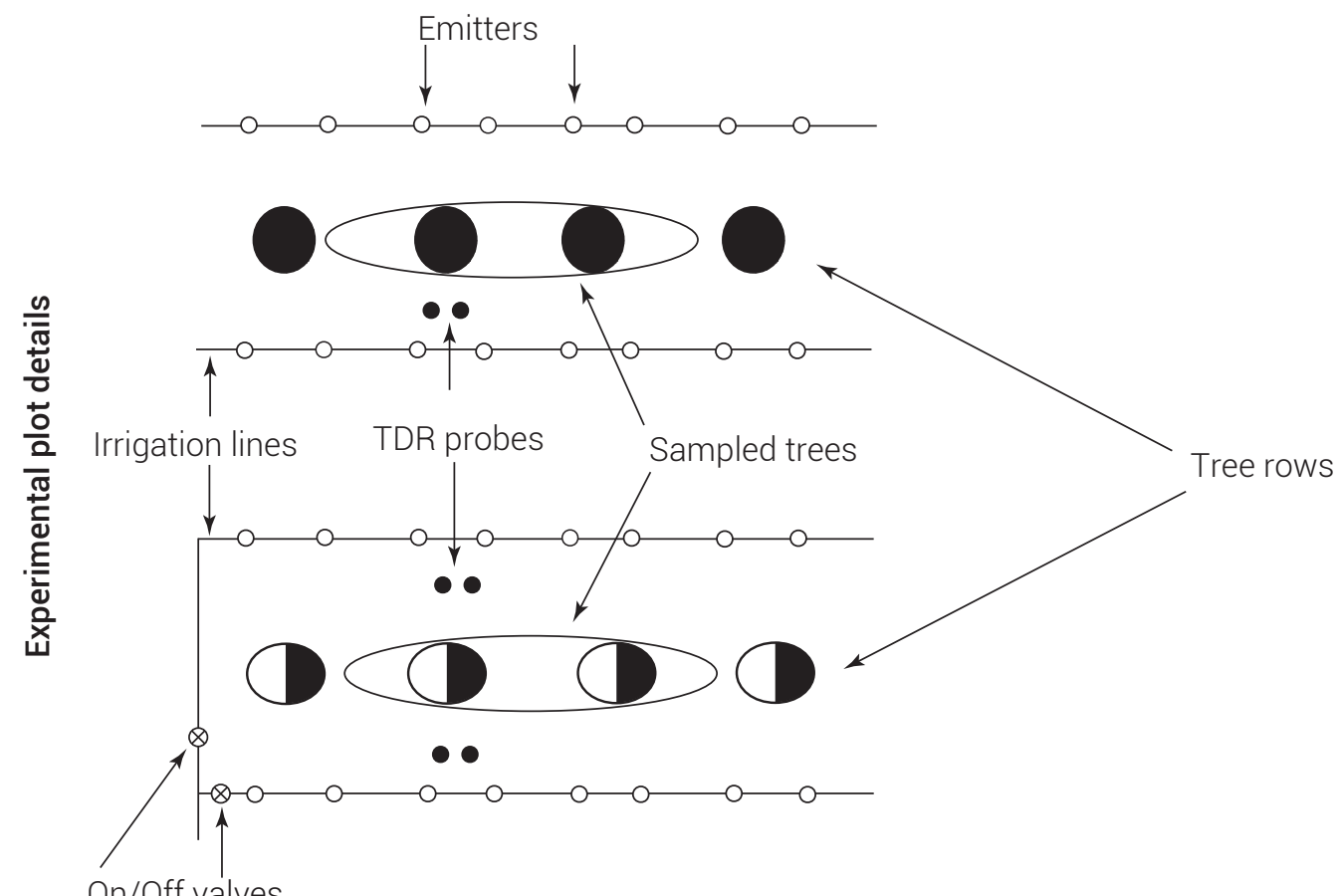

On/Off valves

$$
\begin{aligned}
& \square=\text { Untreated trees } \\
& =\text { Commercial irrigation } \\
& =\text { Partial rootzone drying }
\end{aligned}
$$

Figure 1. Field layout of the experiment orchard, experimental plot distribution, irrigation lines, time domain reflectometry (TDR) probes, and other experimental details. 
This corresponds to a midday $\psi_{\text {leaf }}$ of -2.1 to $-1.8 \mathrm{MPa}$ (Mills et al., 1996; Mpelasoka et al., 2001). However, as indicated previously, this water stress intensity was not developed in this experiment; which indicates that the wetted part of the root system of PRD trees can equilibrate $\psi_{\text {leaf }}$ even during fruit expansion stage (Zegbe and Serna-Pérez, 2012).

Fruit growth pattern was the same between the two treatments because no water stress was developed in PRD trees as previously argued by Zegbe and Serna-Pérez (2012) (Figure 3). Therefore, mean fresh mass, diameter, volume, and dry mass concentration were statistically similar between irrigation treatments (Table 1). In contrast, firmness and total soluble solids concentration tended to be the highest in PRD fruits, which also tended to be redder by having a lower hue angle (Table 1). The only significant difference was observed on the starch pattern index (SPI), which was high in PRD fruits (Table 1). This indicated that PRD fruit reached an early maturity. Under PRD root-toshoot and shoot-to-fruit signalling takes place (Davies et al., 2000), hence root-shoot-fruit signalling process may trigger production of ethylene in the fruit leading to an increase in starch hydrolysis into sugar (Thammawong and Arakawa, 2010). The underlying mechanisms notwithstanding, earlier fruit maturity would have important implications for early fruit marketing.

The CDA suggested a significant difference $(P \leq 0.0001)$ between treatments. This was further corroborated submitting the standardised canonical scores (SCS) from the first canonical variate (CVI) to an analysis of variance. Collectively, fruit quality attributes were significantly different between $\mathrm{Cl}$ and PRD treatments. Mean values (SCS \pm LSD $=0.87$ ) from the CVI were -1.0 for $\mathrm{Cl}$ and 0.9 for PRD fruit. The standardised canonical coefficients were weighed only toward mean fruit fresh mass and SPI, as indicative of advancement in PRD fruit ripening (Szalay et al., 2013). The former was moderately correlated and the latter highly correlated with CVI (Table 2). Discrimination between $\mathrm{Cl}$ and PRD fruits may be based on higher SPI and lower mean fruit fresh mass. The application of CDA was therefore a further confirmation for the FMA in PRD fruit. Findings in cvs. Autumn Rose Fuji (Fallahi et al., 2008) and Pacific Rose $^{\mathrm{TM}}$ apples (Zegbe and Behboudian, 2008) support our results. Also, one week advancement in fruit maturity for $\mathrm{cv}$. Petropride processing tomato under PRD was observed without measurable changes in $\Psi_{\text {leaf }}$ (Zegbe et al., 2003).

We showed that fruit growth rate and mean fresh mass of fruit were unaffected by PRD. However, PRD advanced fruit maturity in terms of high SPI and a tendency for the improvement of TSSC and firmness. Multivariate analysis confirmed that separation between $\mathrm{Cl}$ and PRD fruit was due to higher SPI in PRD fruit when quality attributes were considered collectively. The study was conducted in a commercial orchard where the application of PRD saved

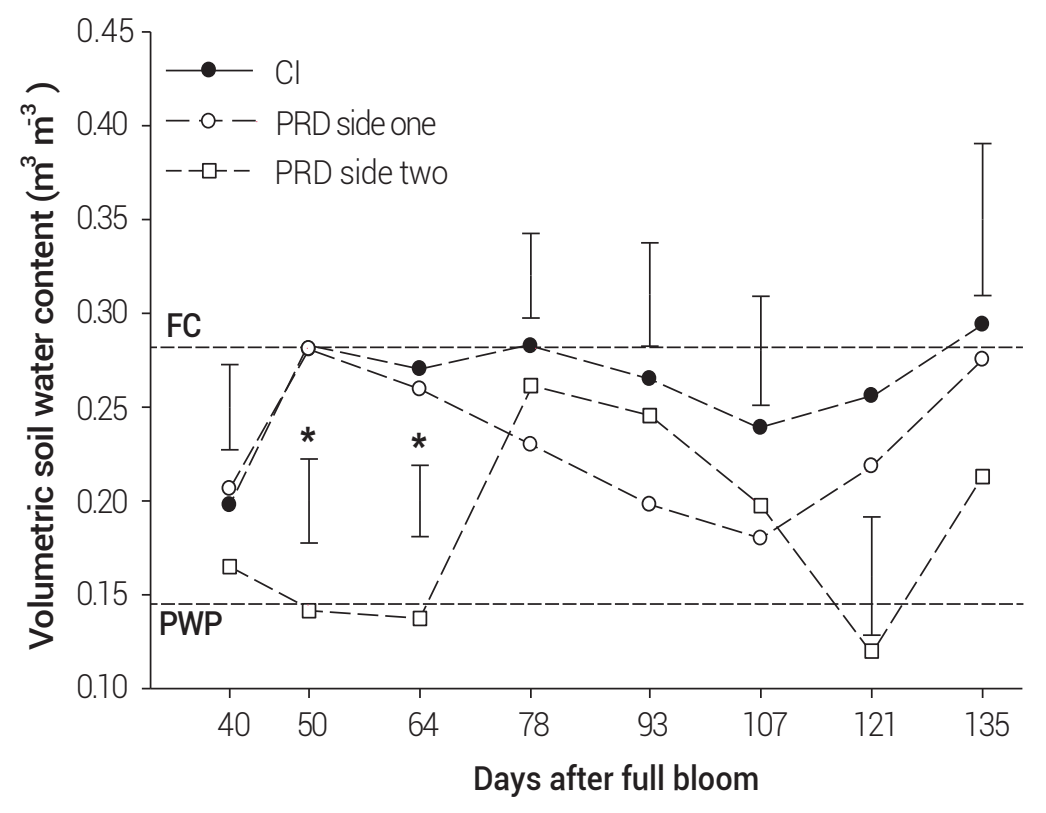

Figure 2. Changes in soil water content ( $\theta$ in the text) in commercially irrigated $(\mathrm{Cl})$ trees and in both sides of partial root zone drying (PRD) trees. The horizontal dashed lines indicate field capacity (FC) and permanent wilting point (PWP) for the orchard's soil. Vertical bars represent the least significant difference and the asterisks indicate significant differences among means at $\mathrm{P} \leq 0.05$. 


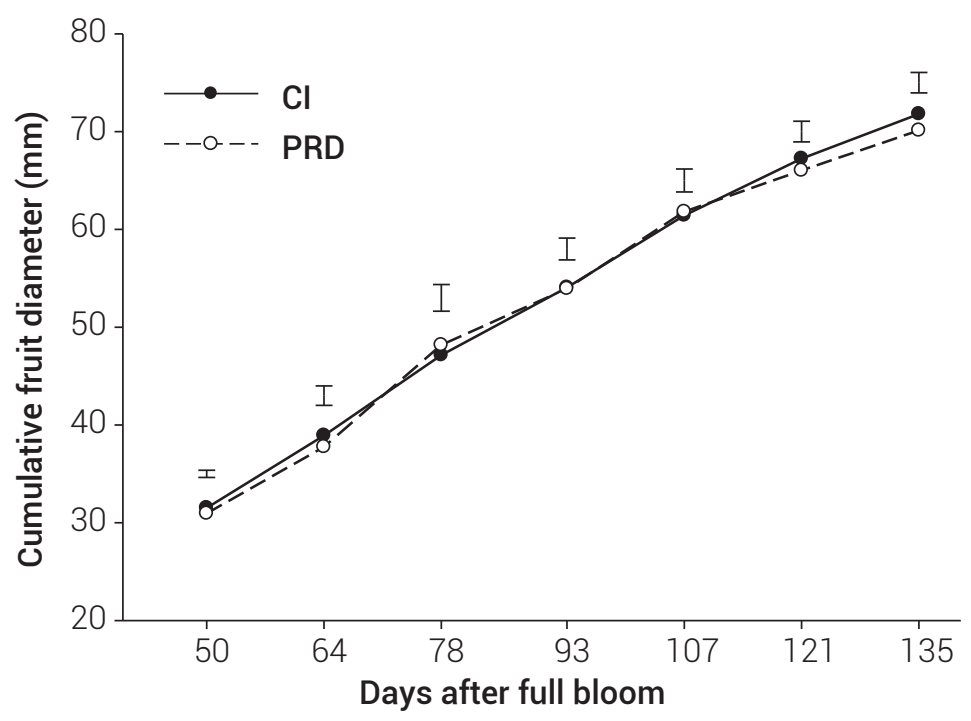

Figure 3. Cumulative fruit growth of Royal Gala apples under commercial irrigation (CI) and partial rootzone drying (PRD). Vertical bars represent the least significant difference at $P \leq 0.05$.

Table 1. Effects of irrigation treatments (ITs) on mean fresh mass of fruit (MFMF), fruit diameter (FD), fruit volume (FV), fruit density (Fden), flesh firmness (FF), dry mass concentration of fruit (DMCF) on a fresh weight (FW) basis, total soluble solids concentration (TSSC), starch pattern index (SPI), and fruit skin colour in terms of hue angle $\left(\mathrm{HA}^{\circ}\right)$. The SPI ranked from 0 (100\% starch) to 6 (no starch).

\begin{tabular}{|c|c|c|c|c|c|c|c|c|c|}
\hline ITs & MFMF (g) & $\mathrm{FD}(\mathrm{mm})$ & $\mathrm{FV}\left(\mathrm{cm}^{3}\right)$ & Fden $\left(\mathrm{g} \mathrm{cm}^{-3}\right)$ & $\mathrm{FF}(\mathrm{N})$ & $\begin{array}{c}\text { DMCF } \\
\left(\mathrm{mg} \mathrm{g}^{-1} \mathrm{FW}\right)\end{array}$ & TSSC (\%) & $\mathrm{SPI}$ & $\mathrm{HA}\left({ }^{\circ}\right)$ \\
\hline $\mathrm{Cl}$ & $167.3 a^{+}$ & $70.3 a^{+}$ & $182.9 a^{\dagger}$ & $0.92 \mathrm{a}^{+}$ & $94.2 \mathrm{a}^{+}$ & $139.4 a^{\dagger}$ & $11.0 \mathrm{a}^{\dagger}$ & $4.4 b^{+}$ & $35.8 a^{+}$ \\
\hline PRD & $146.2 a$ & $67.1 \mathrm{a}$ & $160.0 a$ & $0.92 a$ & $96.9 a$ & 136.0a & 11.9a & $5.1 a$ & $34.3 a$ \\
\hline LSD & 21.5 & 3.4 & 25.5 & 0.04 & 8.1 & 14.1 & 1.0 & 0.41 & 7.3 \\
\hline$P>F$ & 0.05 & 0.06 & 0.07 & 0.97 & 0.41 & 0.46 & 0.43 & 0.01 & 0.63 \\
\hline CV (\%) & 11.9 & 4.4 & 13.3 & 6.0 & 7.0 & 5.5 & 5.6 & 6.1 & 46.5 \\
\hline
\end{tabular}

${ }^{+}$Within columns, means separation between commercial irrigation (CI) and partial rootzone drying (PRD) treatments were by the least significant difference (LSD) test at $P \leq 0.05$. $P>F=$ significance; $C V=$ coefficient of variation.

Table 2. Standardised canonical coefficients (SCC) and correlation coefficients ( $r$ ) for the first canonical variate $(\mathrm{CVI})$ and six fruit quality attributes of Royal Gala apples.

\begin{tabular}{|c|c|c|}
\hline \multirow{2}{*}{ Fruit quality attributes } & \multicolumn{2}{|c|}{$\mathrm{CVI}$} \\
\hline & SCC & $r$ \\
\hline Mean fresh mass of fruit & -6.8 & -0.5 \\
\hline Flesh firmness & 0.3 & 0.2 \\
\hline Dry mass concentration of fruit & -0.3 & -0.2 \\
\hline Total soluble solids concentration & 0.3 & 0.2 \\
\hline Starch pattern index & 0.8 & 0.7 \\
\hline Hue angle & --- & --- \\
\hline Canonical correlation & 0.71 & \\
\hline Eigenvalue & 1.0 & \\
\hline Variance explained (\%) & 100 & \\
\hline Significance & $P \leq 0.0001$ & \\
\hline
\end{tabular}


water by $52 \%$. We therefore recommend PRD for apple in similar agro-ecological areas.

\section{ACKNOWLEDGEMENTS}

This study was supported by the Mexican Government (Secretaría de Eduación Pública and Instituto Nacional de Investigaciones Forestales, Agrícolas y Pecuarias), ENZA New Zealand, and Universidad Autónoma de Zacatecas. We thank Mr. Leon Stallard, the owner of the apple orchard. We also appreciate the comments from the two Referees and the Editor that improved this presentation.

\section{BIBLIOGRAPHY}

Behboudian M. H., J. Marsal, J. Girona and G. Lopez (2011) Quality and yield responses of deciduous fruits to reduced irrigation. Horticultural Reviews 38:149-189.

Caspari H. W., S. Neal and P. Alspach (2004) Partial rootzone drying. A new deficit irrigation strategy for apple? Acta Horticulturae 646:93100.

Davies W. J., M. A. Bacon, D. S. Thompson, W. Sobeih and L. González-Rodríguez (2000) Regulation of leaf and fruit growth in plants growing in drying soil: Exploitation of the plants' chemical signaling system and hydraulic architecture to increase the efficiency of water use in agriculture. Journal of Experimental Botany 51:1617-1626.

Einhorn T. and H. W. Caspari (2004) Partial rootzone drying and deficit irrigation of 'Gala' apples in a semi-arid climate. Acta Horticulturae 664:197-204.

Fallahi E., B. Fallahi and B. Shafii (2008) Effect of irrigation systems and rootstocks on water use, tree growth, fruit quality and mineral nutrients in apples during the third and fourth year after planting. Acta Horticulturae 772:33-39.

Leib B. G., H. W. Caspari, C. A. Redulla, P. K. Andrews and J. J. Jabro (2005) Partial rootzone drying and deficit irrigation of Fuji apples in semi-arid climate. Irrigation Science 24:85-99.

Loveys B. R., P. R. Dry, M. Stoll and M. G. McCarthy (2000) Using plant physiology to improve the water use efficiency of horticultural crops. Acta Horticulturae 537:187-197.

Mills T. M., M. H Behboudian and B. E. Clothier (1996) Water relations, growth, and the composition of 'Braeburn' apple fruit under deficit irrigation. Journal of the American Society for Horticultural Science 121:286-291.

Mpelasoka B. S., M. H. Behboudian and S. R. Green (2001) Water use, yield and fruit quality of lysimeter-grown apple trees: Response to deficit irrigation and to crop load. Irrigation Science 20:107-113.

Reid M. S., C. A. S. Padfield, C. B. Watkins and J. E. Harman (1982) Starch iodine pattern as a maturity index for Granny Smith apples. I. Comparison with flesh firmness and soluble solids content. New Zealand Journal Agricultural Research 25:229-237.

Szalay L., M. Ordidge, G. Ficzek, P. Hadley, M. Tóth and N. H. Battey (2013) Grouping of 24 apple cultivars on the basis of starch degradation rate and their fruit pattern. Horticultural Science 40:93-101.

Thammawong M. and 0. Arakawa (2010) Starch to sugar conversion in 'Tsugaru' apples under ethylene and 1-methylcyclopropene treatments. Journal of Agricultural Science and Technology $12: 617-626$

Zegbe-Domínguez J. A., M. H. Behboudian, A. Lang and B. E. Clothier (2003) Water relations, growth, and yield of processing tomatoes under partial rootzone drying. Journal of Vegetable Crop Production 9:31-40.

Zegbe J. A. and M. H. Behboudian (2008) Plant water status, $\mathrm{CO}_{2}$ assimilation, yield, and fruit quality of 'Pacific Rose ${ }^{\mathrm{TM}}$ ' apple under partial rootzone drying. Advances in Horticultural Science 22:27-32.

Zegbe J. A. and A. Serna-Pérez (2012) Partial rootzone drying to save water while growing apples in a semi-arid region. Irrigation and Drainage 61:251-259. 